\title{
Green Marketing Strategies and Market Barriers to Sustainability Products Design
}

\author{
Larisa Ivascu ${ }^{1+}$ \\ ${ }^{1}$ Politehnica University of Timisoara, Faculty of Management in Production and Transportation, Department \\ of Management, 14 Remus Street, Timisoara, 300191, Romania
}

\begin{abstract}
In the current environment it is increasingly emphasizing the need for involvement in sustainable development. This is a nationally, but also internationally requirement. To succeed in business, the company needs to acquire a commitment to sustainability and to include it in the company's vision. This commitment is an integral part of the company's values and leads to goals attainment. A strong sustainability strategy includes understanding how society, technology and environment influence company processes and conscious modalities to implement sustainable practices throughout every aspect of its business. The paper presents the strategies used for four P's of Marketing and presents the sustainability's barriers encountered in the production of sustainable articles / items. The research is based on public information and observation visits conducted in various companies. In the end the paper, the results, limitations and future research directions are presented.
\end{abstract}

Keywords: Green marketing; sustainability; strategy; sustainable product; sustainable branding.

\section{Introduction}

At international level there is a significant interest in increasing consumer demand and for the companies to move towards a sustainable direction. Sustainable development, as the action can be defined as ... "sustainable development is development that meets the needs of the present without compromising the ability of future generations to meet their own needs" [1]. The market covers various products that meet increasingly more the terms of sustainability, i.e. balanced consumption of resources by design. The focus is increasingly on natural products without dyes, protecting the environment and society, so this directive defines consumer behaviour [2]. So can we talk about market sustainability? In some studies it is shown that one cannot speak of sustainable market because the market is based on principles of maximization (production, consumption and prices). This desirable framework is also used to describe the other possible types of traditional markets. In addition to the above, it is shown through a simple model that only the perfect sustainable market is durable because it is driven by optimal forces (production, consumption and market prices) [3], [4], [5]. Certainly one cannot speak of a sustainable market, but we can talk about the sustainable direction that the consumer market is heading. Companies that adopt the principles of sustainable development due to [6], [7]:

- Improving the image in rural development;

- Improving the environmental footprint of emissions of pollutants;

- Increased commitment to consumers;

- Loyalty and respect of the consumers that find on the market suitable products for healthy living;

- Durability of the conduct of business and the impact on competition.

+ Corresponding author.

E-mail address: larisa.ivascu@upt.ro 
Unlike traditional operating companies based on triple fundamental line: Consumer, Profits, Production, and the sustainable companies are operating on the basis of the triple baseline of sustainability: Social, Economic, and Environment.

Triple fundamental line includes:

- Consumer: companies research the needs and wants of customers and develop products in accordance with demand from the market for recording a maximum profit.

- Profits: most managers assume maximizing profits as the direction of development [8]. Profit maximization is consistent with maximizing the value of the market (i.e. stock price) of the company.

- Production: companies produce what is required in line with the strategy defined. No account is taken of the European global development directions.

Triple sustainability baseline includes the following [7]:

- Environment: the impact of the campaign activities on the environment broadly - natural resources usage, rejecting the entire nature, territory occupation; from the perspective of marketing, from product conception they should be designed in accordance with the imperatives and environmental conditions of the industry.

- Economic: collecting financial performances, their impact on the economic growth in their field of activity and obeying the ethical principles in business; this coordinated marketing activities are conducted in compliance with environmental and social imperatives, but with a balance of economic outlook.

- Social: the social consequences of the company as a whole its representatives: employees, solicitors, clients, local community; the society and its needs must be integrated in product design [9].

The companies which operate under the fundamental triple line lead to a market based on principles of maximization and companies which are included under the umbrella of triple sustainability baselines lead to sustainable market [10]. Further there are considered sustainable market strategies related to marketing mix, but also the barriers encountered in this direction. Finally conclusions and future research directions are presented.

\section{Sustainable Strategies Applied in Marketing}

Green marketing implies developing and promoting products and services that meet the needs of consumers and business users through the balanced use of natural, cultural / societal resources, and economic resources. This entire endeavor is responsible for ensuring a good quality of life now and in the future. Sustainable marketing is not only about actions by the company to highlight its care for the environment or consumers, but adds new methods and requirements to traditional marketing:

- Understand fully the values and behaviors of the purchasers directed towards sustainable development,

- Knowledge of market developments from sustainable perspective,

- Organizational commitment to sustainability and positive relationships with their customers, communities and the planet,

- National and international requirements on sustainable development

Sustainable marketing plan focuses on the marketing mix in order to achieve maximum profit potential while respecting the principles of sustainability. For an effective approach to sustainable marketing, i.e. basic four Ps (product, price, placement and promotion) the sustainability principles should be applied and should be aligned with the overall marketing strategy. Based on these ideas, green marketing plan requires the following [10]:

- The four Ps base should integrate sustainability requirements from the design stage,

- Customer segmentation of the target market must be carried out in accordance with the consumers which identify best with potential customers or buyers of the product or service, 
- Physical products may be sustainable if we take into account ways of reducing the materials used, minimize the negative impacts of the production process, and maximize the efficiency of distribution,

- Changes implemented in the process of packaging, for example to encourage reusable or biodegradable bags; the existence of an inverse correlation with environmental impact in order to reduce the environmental impact of a product while profitability may increase,

- Sustainable goods that can be more costly from the price perspective than traditional products because production processes have to be optimized by reducing the amount of resources used by implementing new techniques and technologies (renewable sources, energy production on its own, waste reuse and others). This should be taken into consideration in developing branding, marketing mix development, and identifying target segment.

- Using different environments to promote through the integration of IT technologies and online media promotion is adequate support to effectively and efficiently reach the target market with a consistent brand message and call to action.

The directions from above contribute to the development of a sustainable marketing plan designed to achieve the company's objectives. Companies' goals are established in the current economic context in which it emphasizes the need to develop a green marketing mix directed toward the environment, technology and society.

Figure 1 presents a conceptual framework of development green strategies applied in marketing based on sustainable development. With the support elements presented and discussed, this model incorporates concepts and important directions. This model is based on the proposals of authors [7], [11], [12].

\section{Barriers of Sustainable Product Development}

All Even if the direction of the development of green products remains viable and a priority, the question arises why some consumers do not buy natural / green products? It discusses the three key barriers facing companies: price, performance, technology and behavior change.

When it comes to natural products there is a clear direction to price and performance level. Often customers do not want to pay more for a better product. Buyer behavior changes according to the dynamic o the environment, so using new technologies these desires can be satisfied. Product performance is ultimately proof of higher financial implications [13]. These barriers can be seen as problems to be solved by each company through different strategies of marketing mix.

\section{The New Rules of Green Marketing and Conclusions}

Green marketing rules contribute to the goals of the company and generate new opportunities. Benefits [14], [15] obtained by applying this green marketing are:

- Profitability: "green products" (bio, natural products) have fewer raw materials, less energy and results in fewer waste.

- Competitive advantage: companies that focus on innovation enjoy an increased competitive advantage.

- Increasing market share: the production of beneficial consumer items and protecting the environment, the company attract new buyers. Also the quality offered contributes to increased market share.

- Best products: products are safer, healthier and not least better.

More and more companies are adopting new rules and procedures for the development of competitive products because it "causes" market dynamics.

Developing sustainable products is a challenge for every company. Finally this challenge involves a number of risks. Therefore, sustainable marketing risks can be divided into four categories: market risks, operational risks, the risks of image and communication risk. In future research we will analyze these classes of risks and how they contribute to the development of new opportunities. 


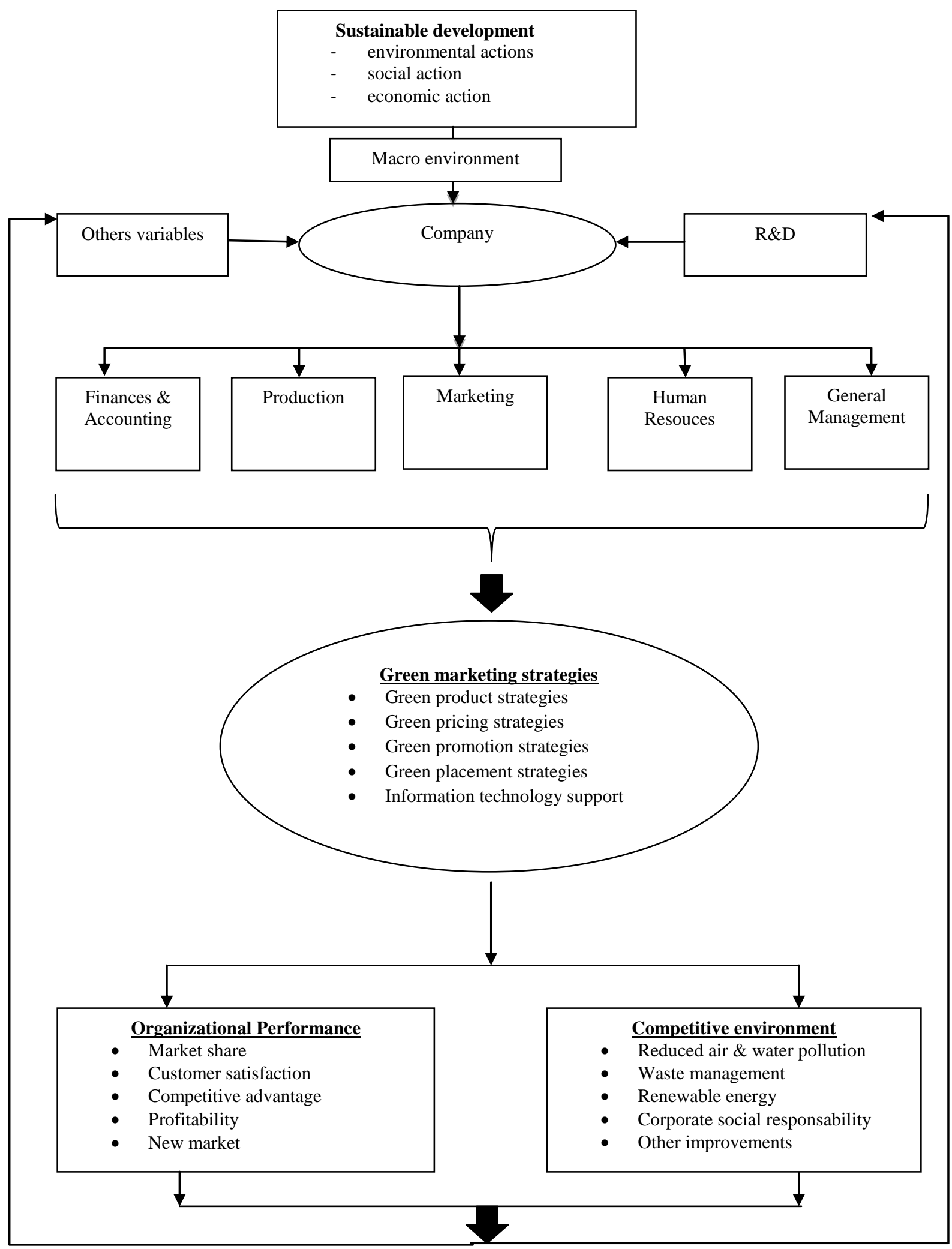

Fig. 1: Conceptual framework of green marketing strategies and sustainable development.

\section{Acknowledgements}

This work was supported by a mobility grant of the Romanian Ministery of Research and Innovation, CNCS - UEFISCDI, project number PN-III-P1-1.1-MC2018-0582, within PNCDI III.

\section{References}

[1] United Nations Economic and Social Council, 2015. Implementing Agenda 21: Report of the Secretary-General 
(1987). Commission on Sustainable Development acting as the preparatory committee for the World Summit on Sustainable Development, Second preparatory session

[2] Draghici, A., Albulescu, C.T., Tamasila, M. (2013). Entrepreneurial attitude as knowledge asset: its impact on the entrepreneurial activity in Europe, 2nd World Conference on Business, Economics and Management (BEM), Procedia Social and Behavioral Sciences 109, 205-209, Turkey.

[3] Munoz, L., (2008). The Traditional Market and the Sustainability Market: Is the Perfect Market Sustainable?, International Journal of Economic Development 3 (4), 1-14.

[4] Artene, A., Domil, A., Duran, V., Duran, D., (2013). Customizing Environmental Management Systems to Optimize Environmental Costs in Romanian SME, 20th IBIMA conference on Entrepreneurship Vision 2020: Innovation, Real Estate investment, Development Sustainability, and Economic Growth.

[5] Mocan, M., Rus, S., Draghici, A., Ivascu, L., Turi, A. (2015). Impact of corporate social responsibility practices on the banking industry in Romania, 2nd Global Conference on Business, Economics, Management and TOURISM (BEMTUR), Procedia Economics and Finance 23, 712-716, Cehia.

[6] Cioca, L.I., Ivascu, L., Rada, E.C., Torretta, V., Ionescu, G., (2015). The Study of Sustainable Development and Technological Impact on CO2 Reducing Conditions: Case Study of Romania, Sustainability Journal 7, 1637-1650.

[7] Izvercian, M., Ivascu, L., Potra, S., (2015). Enterprise Sustainability Management: An Emergent Approach and Research Imperatives, Crafting Global Competitive Economies: 2020 Vision Strategic Planning \& Smart Implementation, 24th IBIMA Conference, 440-449.

[8] Taucean, I.M., Tamasila, M., Strauti, G. (2015). Study on Management Styles and Managerial Power Types for a Large Organization, 13th International Symposium in Management: Management During and After the Economic Crisis, Procedia Social and Behavioral Sciences 221, 66-75, Romania.

[9] European Commission. http://ec.europa.eu/index_ro.htm, Retrieved September 03, 2015.

[10] Ivascu, L., Cioca L.I (2014). Opportunity Risk: Integrated Approach to Risk Management for Creating Enterprise Opportunities, 2nd International Conference on Psychology, Management and Social Science, Advances in Education Research 49, 77-80.

[11] Kinoti, M.W., (2011). Green marketing Intervention Strategies and Sustainable Development: A Conceptual Paper, International Journal of Business and Social Science 23 (2), 263-273.

[12] Moraru, R. I., Babut, G. B., Cioca, L.I. (2014). Rationale and Criteria Development for Risk Assessment Tool Selection in Work Environments, Environmental Engineering and Management Journal 13(6), 1371-1376.

[13] Draghici, A., Baban, C.F., Gogan, M., Ivascu, L.V., (2015). A Knowledge Management Approach for the University-Industry Collaboration in Open Innovation, 2nd Global Conference on Business, Economics, Management and Tourism, Procedia Economics and Finance 23, pp. 23-32.

[14] Katiyar, S., (2015). An Overview of Green Marketing for Indian Market, Abhinav National Monthly Refereed Journal of Research in Commerce \& Management 4(2), 11-16.

[15] Sharma, Y., (2011). Changing consumer behaviour with respect to Green marketing- A case study of consumer durables and retailing, Zenith international journal of multidisciplinary research 1 (4). 